\title{
Dithiocarbamates are strong inhibitors of the beta-class fungal carbonic anhydrases from Cryptococcus neoformans, Candida albicans and Candida glabrata
}

\author{
Simona Maria Monti ${ }^{a}$, Alfonso Maresca ${ }^{b}$, Francesca Viparelli ${ }^{a}$, Fabrizio Carta ${ }^{\text {b }}$, Giuseppina De Simone ${ }^{\text {a }}$, \\ Fritz A. Mühlschlegel ${ }^{\mathrm{c}}$, Andrea Scozzafava ${ }^{\mathrm{b}}$, Claudiu T. Supuran ${ }^{\mathrm{b}, *}$ \\ a Istituto di Biostrutture e Bioimmagini-CNR, via Mezzocannone 16, 80134 Napoli, Italy \\ ${ }^{\mathrm{b}}$ Università degli Studi di Firenze, Polo Scientifico, Laboratorio di Chimica Bioinorganica, Rm. 188, Via della Lastruccia 3, 50019 Sesto Fiorentino (Florence), Italy \\ ${ }^{\mathrm{c}}$ School of Biosciences, University of Kent, Canterbury, Kent CT2 7NJ, United Kingdom
}

\section{A R T I C L E I N F O}

Article history:

Received 9 November 2011

Revised 6 December 2011

Accepted 8 December 2011

Available online 11 December 2011

\section{Keywords:}

Carbonic anhydrase

Dithiocarbamate

Beta-class enzyme

Inhibitor

Cryptococcus neoformans

Candida albicans

Candida glabrata

\begin{abstract}
A B S T R A C T
A series of $\mathrm{N}$-mono- and $\mathrm{N}, \mathrm{N}$-disubstituted dithiocarbamates have been investigated as inhibitors of three $\beta$-carbonic anhydrases (CAs, EC 4.2.1.1) from the fungal pathogens Cryptococcus neoformans, Candida albicans and Candida glabrata, that is, Can2, CaNce103 and CgNce103, respectively. These enzymes were inhibited with efficacies between the subnanomolar to the micromolar range, depending on the substitution pattern at the nitrogen atom from the dithiocarbamate zinc-binding group. This new class of $\beta$-CA inhibitors may have the potential for developing antifungal agents with a diverse mechanism of action compared to the clinically used drugs for which drug resistance was reported, and may also explain the efficacy of dithiocarbamates as agricultural antifungal agents.
\end{abstract}

(c) 2011 Elsevier Ltd. All rights reserved.
Dithiocarbamates (DTCs) are a well-known class of compounds, which complexate metal ions due to the presence of the anionic $\mathrm{CS}_{2}^{-}$moiety, which can coordinate mono- or bidentately a variety of transition heavy metal ions. ${ }^{1,2}$ Furthermore, many such derivatives (e.g., the manganese(II), copper(II) or zinc(II) complexes of aliphatic DTCs) have applications in agriculture as antifungals for the protection of crops, as well as in medicine. ${ }^{1,2}$ Although known for at least six decades, it is amazing that they have been scarcely investigated as metalloenzyme inhibitors. Apart from being investigated as tyrosinase inhibitors (a copper enzyme which shows micromolar affinity for some of these compounds $)^{2}$ only one paper reported that $\mathrm{N}, \mathrm{N}$-diethyl-dithiocarbamate inhibits bovine cobal$\mathrm{t}(\mathrm{II})$-substituted carbonic anhydrase (CA, EC 4.2.1.1). ${ }^{3}$

The CA superfamily of enzymes catalyzes a simple but physiologically essential process, hydration of carbon dioxide to bicarbonate and a proton. ${ }^{4-8}$ These metalloenzymes are known in nature as five different, genetically distinct families, the $\alpha-, \beta-$, $\gamma-, \delta$ - and $\zeta$-CAs. ${ }^{4-10}$ Whereas $\alpha$-, $\beta$ - and $\delta$-CAs use $\mathrm{Zn}(\mathrm{II})$ ions at the active site, the $\gamma$-CAs are $\mathrm{Fe}(\mathrm{II})$ enzymes (but they are active also with bound $\mathrm{Zn}(\mathrm{II})$ or $\mathrm{Co}(\mathrm{II})$ ions), whereas the $\zeta$-class uses

\footnotetext{
* Corresponding author. Tel.: +39 055 4573005; fax: +39 0554573385 .

E-mail address: claudiu.supuran@unifi.it (C.T. Supuran).
}

$\mathrm{Cd}(\mathrm{II})$ or $\mathrm{Zn}(\mathrm{II})$ to perform the physiologic reaction catalysis. ${ }^{4-10}$ The metal ion from the enzyme cavity is essential for the binding of most classes of CA inhibitors (CAIs) investigated so far, of which the sulfonamides and their bioisosteres as well as the metal complexing anions (cyanide, thiocyanate, azide, etc.) are the main representatives. ${ }^{4-8}$ Such inhibitors coordinate to the metal ion from the CA active site as anions. ${ }^{4-10}$

$\beta$-CAs have been described in a great number of species belonging to the Archaea and Bacteria domains, ${ }^{4-14}$ whereas in Eukaryotes only yeasts, ${ }^{9}$ microscopic fungi ${ }^{9-11}$ and very recently arthropods ${ }^{15}$ were shown to encode such enzymes. ${ }^{15,16} \beta$-CAs were recently characterized in several bacterial/fungal human pathogens, such as among others the fungi/yeasts Candida albicans, Candida glabrata, Cryptococcus neoformans, and Saccharomyces cerevisi$a e^{4,6,7,9,12,15,16}$ Many of these enzymes were investigated for their inhibition with sulfonamides and anions, in the search of selective $\beta$-CA inhibitors with potential therapeutic applications. ${ }^{9,10}$

Recently we have investigated some complex, less commonly used inorganic anions as CAIs, ${ }^{13,14}$ detecting trithiocarbonate $\left(\mathrm{CS}_{3}^{2-}\right)$ as an interesting inhibitor of several $\alpha$-CA isoforms. We have also proposed that compounds possessing this new zinc-binding function found in trithiocarbonate, such as for example the dithiocarbamates $\left(\mathrm{R}_{2} \mathrm{~N}-\mathrm{CS}_{2}^{-}\right)$, might possess better inhibitory properties 
compared to the simple inorganic anion mentioned above. ${ }^{13,14}$ In fact in the X-ray crystal structure of the human (h) CA isoform hCA II in complex with trithiocarbonate (which acts as a low micromolar hCA II inhibitor $)^{13}$ we have observed a favorable binding of this simple anion to the zinc ion from the enzyme active site, as shown in Figure 1, and the possibility to us this new zinc binding group (ZBG) for drug design purposes. Indeed, one sulfur atom of trithiocarbonate is coordinated to the $\mathrm{Zn}(\mathrm{II})$ ion, whereas this same atom and a second sulfur atom participate in two hydrogen bonds with the $\mathrm{OH}$ and $\mathrm{NH}$ moieties of Thr $199,{ }^{14}$ an amino acid residues conserved and essential for all $\alpha$-CAs investigated so far. ${ }^{4-8}$ Furthermore, the third sulfur atom of the bound inhibitor is orientated in such a way that it makes no contacts and is exposed to the solvent, allowing us to hypothesize that the $\mathrm{CS}_{2}^{-}$ZBG might easily be usable to design CAIs of novel classes. The DTCs are compounds which in fact possess this ZBG, to which a nitrogen atom with one or two different substituents is also attached, and furthermore, they are easily accessible through a very simple chemistry, that is, reaction of carbon disulfide with amines in the presence of bases. ${ }^{17}$

This prediction has recently been validated by the report that DTCs of types $\mathbf{1 - 2 7}^{17}$ (as well as some agriculturally used DTC metal complexes) ${ }^{18}$ possess highly effective inhibitory properties against four human (h) $\alpha$-CA isoforms, hCA I, hCA II, hCA IX and hCA XII as well as interesting activity against the enzyme from an endangered sturgeon species. ${ }^{17,18}$

However, this type of compounds has not been investigated so far for its interaction with $\beta$-class CAs. Indeed, whereas in the $\alpha$ CAs the catalytically crucial $\mathrm{Zn}$ (II) ion is coordinated by three His residues and a water molecule/hydroxide ion (which is being replaced by the inhibitor molecule), ${ }^{4-8}$ the $\beta$-CAs have the $\mathrm{Zn}$ (II) coordinated by two Cys and one His residues, whereas the fourth metal ion ligand is in most cases the water molecule/hydroxide ion. ${ }^{9,19}$ The inhibition mechanism of the $\alpha$ - and $\beta$-CAs (at least with zinc binders) is however quite similar, with the inhibitor replacing the fourth, non protein zinc ligand. ${ }^{6,7}$ This is the reason why we report here the investigation of DTCs for their interaction with three $\beta$-CAs from the fungal pathogens $C$. neoformans, $C$. albicans, and $C$. glabrata (Can2, CaNce103 and CgNce103, respectively). This is the first report on the inhibition of $\beta$-CAs with a new class of inhibitors, the DTCs. ${ }^{20,21}$

A series of 27 DTCs possessing the general formula $\mathrm{R}^{1} \mathrm{R}^{2} \mathrm{~N}-\mathrm{CSS}$ $\mathrm{M}^{+}, \mathbf{1 - 2 7}$, where $\mathrm{R}^{1}$ is $\mathrm{H}$, alkyl, substituted alkyl; $\mathrm{R}^{2}$ is alkyl, aryl,

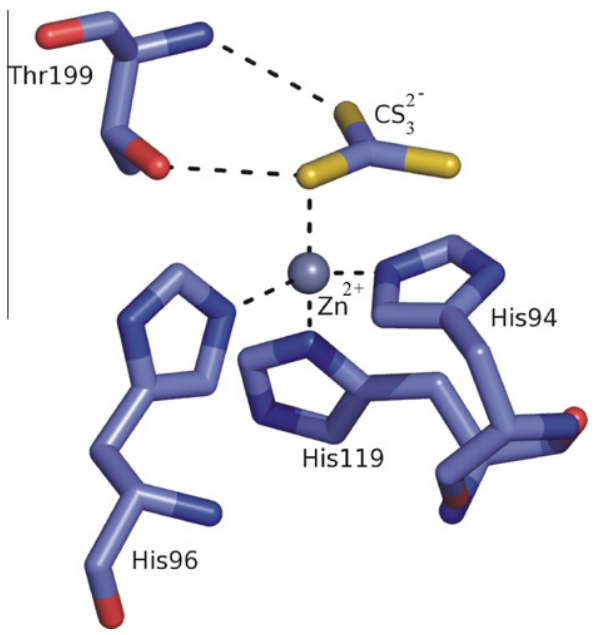

Figure 1. Trithiocarbonate $\left(\mathrm{CS}_{3}^{2-}\right)$, a recently investigated low micromolar $\mathrm{CAI}{ }^{13}$ binds to the $\mathrm{Zn}^{2+}$ in the hCA II active site in a slightly distorted tetrahedral geometry of the metal ion, allowing for derivatizations of the sulfur atom not interacting with the metal ion or Thr199. The protein zinc ligands (His94, 96 and 119) and Thr199 with which the inhibitoirs makes two hydrogen bonds, ${ }^{14}$ are also shown (PDB code $3 \mathrm{~K} 7 \mathrm{~K})$. hetaryl (but $R^{1} R^{2}$ can also be included in a cyclic structure, such as the pyrrolidine dithiocarbamate $\mathbf{1 5}$, the morpholine-dithiocarbamate $\mathbf{2 4}$, or the $S$-prolyl-dithiocarbamate $\mathbf{2 7}$, among others) and $\mathrm{M}^{+}$is $\mathrm{Na}^{+}, \mathrm{K}^{+}$or triethylammonium, have been investigated for their inhibitory activity against three fungal isoforms, Can2, CaNce103 and CgNce103, respectively (Table 1). The inhibition of the human isoforms hCA II (belonging to the $\alpha$-CA class) is also shown in Table 1 for comparison reasons, as these data were reported in our previous contribution. ${ }^{17}$ The clinically used sulfonamide inhibitor acetazolamide, AZA (5-acetamido-1,3,4thiadiazole-sulfonamide) has also been included among the tested compounds, as it is a standard $\alpha / \beta-C A$ inhibitor. ${ }^{4}$

The following structure-activity relationship (SAR) can be observed from data of Table 1:(i) against Can2 the DTCs 1-27 represent a class of highly potent inhibitors, with inhibition constants in the range of $0.75-876 \mathrm{nM}$ (Table 1 ). A quite straightforward SAR may be observed for the inhibition of this enzyme with the DTCs investigated here. Thus, for compounds obtained from primary amines and carbon disulfide, of type 1-12, a very good inhibitory activity $\left(K_{\mathrm{I}} \mathrm{S}<10 \mathrm{nM}\right)$ was observed for most investigated DTCs. The highly effective inhibitors $1-3,5,8,9$ and $12\left(K_{\mathrm{I}} \mathrm{S}\right.$ of 4.8 $7.1 \mathrm{nM}$ ) incorporated aromatic, aliphatic, and heterocyclic moieties. Several derivatives, that is, 4, 6, 7, 10 and 11, incorporating aliphatic, arylalkyl, hetaryl and amino acyl moieties (compound $\mathbf{6}$ is a tris-DTC), were slightly less effective as Can2 inhibitors, with $K_{\mathrm{I}} \mathrm{s}$ of 21.7-71.3 nM. It is obvious that a very large range of substituents at the nitrogen atom lead to highly effective Can2 inhibitors belonging to the DTC class. For the compounds obtained from secondary amines and carbon disulfide, of type 13-27, the SAR was slightly more complex. Thus, the dimethyl- and diethyl-DTCs 12 and 13 were the least inhibitory compounds among the investigated derivatives, with $K_{\mathrm{I}} \mathrm{S}$ in the range of 800-900 nM. However, an increase of the aliphatic moieties chain, such as in 16-20 (or their incorporation in a cyclic structure, such as in 15) leads to a drastic and gradual increase of the inhibitory capacity, these compounds possessing $K_{\mathrm{I}} \mathrm{S}$ in the range of $0.75-88.1 \mathrm{nM}$. Indeed, the $\mathrm{N}, \mathrm{N}$-dihexyl-DTC 19 is a subnanomolar Can2 inhibitor, being, as far as we know, the best ever reported CAI against this fungal enzyme. The presence of two hydroxyethyl moieties in the DTC 21 leads on the other hand again to a less effective CAI, with a $K_{\mathrm{I}}$ of $65.5 \mathrm{nM}$ (compared to the structurally related diethyl-DTC 13 which is a weak CAI, with a $K_{\mathrm{I}}$ of $802 \mathrm{nM}$ ). The compounds possessing one methyl and one aryl/arylalkyl moiety, such as $\mathbf{2 2}$ and $\mathbf{2 3}$ were more effective CAIs compared to 21, significantly inhibiting this enzyme, with $K_{\mathrm{I}} \mathrm{S}$ in the range of 8.3-15.2 nM (Table 1). Excellent inhibition has been observed also with the heterocyclic compounds 24-27 $\left(K_{\mathrm{I}} \mathrm{s}\right.$ in the range of 5.4-7.3 nM). Thus, a large number of substitution patterns lead to highly effective inhibitors, also for the disubstituted compounds, and small structural changes drastically influence the enzyme inhibitory activity of these compounds. Mention should be made that many representatives of this new class of CAIs, were more efficient Can2 inhibitors compared to the sulfonamide AZA ( $K_{\mathrm{I}}$ of $\left.10.5 \mathrm{nM}\right)$ ).(ii) The second fungal CA investigated here, CaNce103, was also highly sensitive to inhibition with DTCs, the derivatives 1-27 showing $K_{\mathrm{I}} \mathrm{S}$ in the range of 4.2$962 \mathrm{nM}$, whereas the sulfonamide compound AZA was a much weaker inhibitor, with a $K_{\mathrm{I}}$ of $132 \mathrm{nM}$ (Table 1 ). For compounds obtained from primary amines and carbon disulfide, of type 1-12, a very good inhibitory activity $\left(K_{\mathrm{I}} \mathrm{S}<10 \mathrm{nM}\right)$ was observed for most investigated DTCs except the tris-derivative $\mathbf{6}$ which had an order of magnitude less inhibition ( $K_{\mathrm{I}}$ of $466 \mathrm{nM}$ ) compared to the other compounds. The highly effective inhibitors $1-3,5,8,9$ and $12\left(K_{\mathrm{I}} \mathrm{S}\right.$ of 5.3-7.5 nM) incorporated aromatic, aliphatic, and heterocyclic moieties. Several derivatives, that is, 4, 7, 10 and 11, incorporating aliphatic, arylalkyl, hetaryl and amino acyl moieties, were slightly less effective as CaNce103 inhibitors, with $K_{\mathrm{I}} \mathrm{s}$ of 37.3-61.3 nM. For 
Table 1

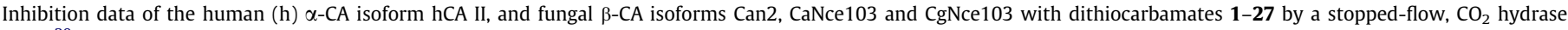
assay. $^{20}$

\begin{tabular}{|c|c|c|c|c|c|c|c|}
\hline \multirow[t]{2}{*}{ Compd } & \multirow[t]{2}{*}{$\mathrm{R}^{1}$} & \multirow[t]{2}{*}{$\mathrm{R}^{2}$} & \multicolumn{4}{|c|}{$K_{\mathrm{I}}^{*}(\mathrm{nM})$} & \multirow[t]{2}{*}{ M } \\
\hline & & & hCA II & Can2 & CaNce103 & CgNce103 & \\
\hline 1 & $\mathrm{H}$ & $\mathrm{Ph}$ & 4.5 & 4.8 & 6.4 & 7.8 & $\mathrm{Et}_{3} \mathrm{NH}$ \\
\hline 2 & $\mathrm{H}$ & $\mathrm{O}\left[\left(\mathrm{CH}_{2} \mathrm{CH}_{2}\right)\right]_{2} \mathrm{~N}$ & 3.6 & 5.6 & 6.6 & 9.2 & $\mathrm{~K}$ \\
\hline 3 & $\mathrm{H}$ & $\operatorname{MeN}\left[\left(\mathrm{CH}_{2} \mathrm{CH}_{2}\right)\right]_{2} \mathrm{~N}$ & 33.0 & 7.1 & 7.5 & 8.4 & $\mathrm{~K}$ \\
\hline 4 & $\mathrm{H}$ & 2-Butyl & 29.4 & 71.3 & 50.8 & 88.2 & K \\
\hline 5 & $\mathrm{H}$ & $\mathrm{O}\left[\left(\mathrm{CH}_{2} \mathrm{CH}_{2}\right)\right]_{2} \mathrm{~N}\left(\mathrm{CH}_{2}\right)_{2}$ & 36.3 & 6.6 & 6.0 & 8.4 & $\mathrm{~K}$ \\
\hline $6^{* *}$ & $\mathrm{H}$ & $\mathrm{N}\left[\left(\mathrm{CH}_{2} \mathrm{CH}_{2}\right) \mathrm{N}\right]_{3}$ & 13.5 & 60.5 & 466 & 85.9 & $\mathrm{~K}$ \\
\hline 7 & $\mathrm{H}$ & $\mathrm{PhCH}_{2}$ & 0.7 & 21.7 & 37.3 & 34.5 & $\mathrm{Na}$ \\
\hline 8 & $\mathrm{H}$ & 4-PyridylCH${ }_{2}$ & 16.6 & 5.7 & 5.3 & 8.7 & $\mathrm{Et}_{3} \mathrm{NH}$ \\
\hline 9 & $\mathrm{H}$ & {$\left[\left(\mathrm{CH}_{2}\right)_{5} \mathrm{~N}\right] \mathrm{CH}_{2} \mathrm{CH}_{2}$} & 20.3 & 5.1 & 7.5 & 6.0 & $\mathrm{~K}$ \\
\hline 10 & $\mathrm{H}$ & 2-Thiazolyl & 4.6 & 64.4 & 58.5 & 72.3 & $\mathrm{Et}_{3} \mathrm{NH}$ \\
\hline 11 & $\mathrm{H}$ & $\mathrm{KOOCCH}_{2}$ & 325 & 50.8 & 61.3 & 47.0 & $\mathrm{~K}$ \\
\hline 12 & $\mathrm{H}$ & Imidazol-1-yl- $\left(\mathrm{CH}_{2}\right)_{3}$ & 24.7 & 6.7 & 5.3 & 7.2 & A \\
\hline 13 & $\mathrm{Me}$ & Me & 6910 & 876 & 962 & 913 & $\mathrm{Na}$ \\
\hline 14 & Et & Et & 3100 & 802 & 950 & 874 & $\mathrm{Na}$ \\
\hline 15 & $\left(\mathrm{CH}_{2}\right)_{5}$ & & 27.5 & 64.5 & 62.1 & 72.9 & $\mathrm{Na}$ \\
\hline 16 & $\mathrm{n}-\mathrm{Pr}$ & $n-\operatorname{Pr}$ & 5.5 & 88.1 & 69.4 & 76.2 & $\mathrm{Na}$ \\
\hline 17 & $\mathrm{n}-\mathrm{Bu}$ & $n-\mathrm{Bu}$ & 50.9 & 75.8 & 67.0 & 73.2 & $\mathrm{Na}$ \\
\hline 18 & iso-Bu & Iso-Bu & 0.95 & 6.2 & 6.0 & 5.7 & $\mathrm{Na}$ \\
\hline 19 & n-Hex & $n$-Hex & 51.3 & 0.75 & 6.3 & 3.9 & $\mathrm{Na}$ \\
\hline 20 & Et & $n-\mathrm{Bu}$ & 27.8 & 7.6 & 5.7 & 7.1 & $\mathrm{Na}$ \\
\hline 21 & $\mathrm{HOCH}_{2} \mathrm{CH}_{2}$ & $\mathrm{HOCH}_{2} \mathrm{CH}_{2}$ & 4.0 & 65.5 & 69.0 & 70.3 & $\mathrm{Na}$ \\
\hline 22 & $\mathrm{Me}$ & $\mathrm{Ph}$ & 21.5 & 15.2 & 16.8 & 14.9 & $\mathrm{Na}$ \\
\hline 23 & Me & $\mathrm{PhCH}_{2}$ & 25.4 & 8.3 & 6.5 & 7.4 & $\mathrm{Na}$ \\
\hline 24 & \multicolumn{2}{|c|}{$\mathrm{O}\left[\left(\mathrm{CH}_{2} \mathrm{CH}_{2}\right)\right]_{2}$} & 0.95 & 5.4 & 4.2 & 7.8 & $\mathrm{Na}$ \\
\hline 25 & \multicolumn{2}{|c|}{$\mathrm{NaS}_{2} \mathrm{CN}\left[\left(\mathrm{CH}_{2} \mathrm{CH}_{2}\right)\right]_{2}$} & 0.92 & 6.3 & 7.4 & 7.7 & $\mathrm{Na}$ \\
\hline 26 & \multicolumn{2}{|c|}{$(\mathrm{NC})(\mathrm{Ph}) \mathrm{C}\left(\mathrm{CH}_{2} \mathrm{CH}_{2}\right)_{2}$} & 40.8 & 7.3 & 7.2 & 7.6 & $\mathrm{~N}$ \\
\hline $27^{\#}$ & \multicolumn{2}{|c|}{$(S)-\left[\mathrm{CH}_{2} \mathrm{CH}_{2} \mathrm{CH}_{2} \mathrm{CH}(\mathrm{COONa})\right]$} & 17.3 & 6.4 & 6.2 & 7.2 & $\mathrm{Na}$ \\
\hline- & \multicolumn{2}{|c|}{ AZA (acetazolamide) } & 12 & 10.5 & 132 & 11 & - \\
\hline
\end{tabular}

$\mathrm{A}=$ imidazol-1-yl- $\left(\mathrm{CH}_{2}\right)_{3} \mathrm{NH}_{3}{ }^{+}$.

* Errors in the range of $\pm 10 \%$ of the reported values, by a $\mathrm{CO}_{2}$ hydrase assay method (from three different measurements).

** Tris-dithiocarbamate.

\# (S)-proline dithiocarbamate.

the secondary DTCs 13-27 again the simple derivatives incorporating methyl and ethyl groups (13 and 14) were the weakest inhibitors in the series ( $K_{\mathrm{I}} \mathrm{S}$ in the range of $\left.950-962 \mathrm{nM}\right)$. The increase of the aliphatic chain or its cyclization leads to more effective CAIs, with compounds 15-20 having $K_{\mathrm{I}} \mathrm{s}$ in the range of 5.7-69.4 nM. The bis-dihydroxyethyl, methyl-phenyl and methyl-benzyl DTCs 2123 were rather effective inhibitors $\left(K_{\mathrm{I}} \mathrm{S}\right.$ of $\left.6.5-69.0 \mathrm{nM}\right)$, but the remaining derivatives (24-27) were highly effective, low nanomolar CAIs against this isoform, with $K_{\mathrm{I}} \mathrm{S}$ in the range of $4.2-7.4 \mathrm{nM}$. Again, mono, bis- or tris-DTCs showed highly effective CA inhibitory properties against this fungal enzyme.(iii) CgNce103 was also highly sensitive to DTCs as CAIs, compounds 1-27 investigated here showing inhibition constants in the range of 3.9-913 nM. SAR was also rather similar to what discussed above for the other two $\beta$-CAs, which are orthologs of the $C$. glabrata enzyme. ${ }^{9}$ Thus, both mono- and di-substituted DTC lead to effective inhibitors. Among the most effective such compounds were the following mono-substituted DTCs, $\mathbf{1 - 3}, \mathbf{5}, \mathbf{8}, \mathbf{9}$, and $\mathbf{1 2}$, as well as the following $N, N$-disubstituted DTCs, 18-20, 23-27, which had $K_{\mathrm{I}} \mathrm{S}<10 \mathrm{nM}$ (Table 1$)$. Medium potency inhibition $\left(K_{\mathrm{I}} \mathrm{S}\right.$ between $\left.14.9-88.2 \mathrm{nM}\right)$ was observed for $4,6,7,10,11,15-17,21$ and 22 , whereas the weakest CgNce103 inhibitors were the simple $N, N$-dimethyl/diethyl derivatives 13 and $14\left(K_{\mathrm{I}} \mathrm{S}\right.$ of $\left.874-913 \mathrm{nM}\right)$.(iv) All these enzymes were inhibited by DTCs, although Can2 seems to be slightly more sensitive to this class of compounds compared to CaNce103 and CgNce103. In several cases a certain DTC showed a better inhibitory profile against the last two enzymes than against Can2 but differences were not important. This is probably due to the fact that these $\beta$-CAs show a rather high degree of homology, especially for the active site residues ${ }^{4-7}$ (Table 1).(v) Many DTCs were more effective fungal CA inhibitors compared to the clinically used sulfonamide AZA, although this compound is a strong inhibitor of many mammalian/bacterial/fungal $\alpha$ - and $\beta-C A s .{ }^{4-7}(\mathrm{vi})$ The DTCs showed effective inhibition of both $\alpha$-class and $\beta$-class enzymes, and also the SAR for inhibiting the two types of enzymes were rather similar, as seen from data of Table 1 . This is probably due to the fact that the inhibition mechanism is similar for the two categories of enzymes, with the inhibitor coordinating to the metal ion from the enzyme cavity (although the active sites of the two classes of enzymes are very different, probably the coordination interaction between the catalytic metal ion and the anion DTC inhibitor is the preponderant interaction, explaining thus the high affinity of these inhibitors to these CAs).

But what is the significance of these findings? We consider that at least two important aspects can be derived from the data presented here. First, DTCs and some of their complexes such as maneb 28 and propineb 29 (Fig. 2) are widely used in agriculture as fungicides. ${ }^{18,22}$ As far as we know, their antifungal target is not well defined. Here we propose that such DTCs may act as potent inhibitors of fungal CAs which therefter lead to the inhibition of pathways critical for the survival of the pathogen. Indeed, several groups showed ${ }^{11}$ that fungal CAs and adenylate cyclase participate in a sensing mechanism essential for the pathogen's life cycle and that its perturbation (e.g., by CA inhibition with the sulfonamide<smiles>CCCCCCCCC(=S)SC(=S)NCC(C)C(=S)SCC</smiles>

28: Maneb

29: Propineb

Figure 2. Chemical structure of fungicides maneb $\mathbf{2 8}$ and propineb $\mathbf{2 9}$ widely used in agriculture. 
ethoxzolamide) may be lethal to the organism. ${ }^{11}$ Obviously, we do not present in vivo data here, but this hypothesis is worth to be verified in future work.

On the other hand, various degrees of resistance, mainly in the case of $C$. glabrata and $C$. albicans infections, were reported with presently used antifungal agents. ${ }^{23,24}$ It is thus critical to explore alternative pathways for inhibiting the growth and virulence of these pathogens with agents belonging to different pharmacological classes. The DTCs explored here may be such agents but they should be investigated for their in vivo efficacy.

In conclusion, we evaluated a series of $N$-mono- and $N, N$-disubstituted dithiocarbamates as inhibitors of three fungal $\beta$-CAs from the pathogens $C$. neoformans, $C$. albicans, and $C$. glabrata. All these enzymes were inhibited with efficacies between the subnanomolar to the micromolar one, depending on the substitution pattern at the nitrogen atom from the dithiocarbamate zinc-binding group. Aryl, arylalkyl-, heterocyclic as well as aliphatic such moieties led to potent fungal $\beta$-CA inhibitors in both the $N$-mono- and $N, N$ disubstituted dithiocarbamate series. This new compounds may have the potential for developing antifungal agents with a diverse mechanism of action compared to the clinically used drugs for which many strains exhibit multi-drug resistance.

\section{Acknowledgment}

This work was supported by an EU FP7 research grant (Metoxia project).

\section{References and notes}

1. Marzano, C.; Ronconi, L.; Chiara, F.; Giron, M. C.; Faustinelli, I.; Cristofori, P.; Trevisan, A.; Fregona, D. Int. J. Cancer 2011, 129, 487.

2. Amin, E.; Saboury, A. A.; Mansuri-Torshizi, H.; Moosavi-Movahedi, A. A. J. Enzyme Inhib. Med. Chem. 2010, 25, 272.

3. Morpurgo, L.; Desideri, A.; Rigo, A.; Viglino, P.; Rotilio, G. Biochim. Biophys. Acta. 1983, 746, 168.

4. (a) Supuran, C. T. Nat. Rev. Drug Disc. 2008, 7, 168; (b) Supuran, C. T. Bioorg. Med. Chem. Lett. 2010, 20, 3467.

5. (a) Neri, D.; Supuran, C. T. Nat. Rev. Drug Disc. 2011, 10, 767; (b) Pastorekova, S.; Parkkila, S.; Pastorek, J.; Supuran, C. T. J. Enzyme Inhib. Med. Chem. 2004, 19, 199.

6. (a) Supuran, C. T. Future Med. Chem. 2011, 3, 1165; (b) Supuran, C. T. Mol. Divers. 2011, 15, 305

7. Supuran, C. T. Front. Pharmacol. 2011, 2, 34.

8. Supuran, C. T.; Scozzafava, A.; Casini, A. Med. Res. Rev. 2003, 23, 146

9. (a) Schlicker, C.; Hall, R. A.; Vullo, D.; Middelhaufe, S.; Gertz, M.; Supuran, C. T.; Muhlschlegel, F. A.; Steegborn, C. J. Mol. Biol. 2009, 385, 1207; (b) Innocenti, A.; Vullo, D.; Scozzafava, A.; Casey, J. R.; Supuran, C. T. Bioorg. Med. Chem. Lett. 2005, 15, 573; (c) Innocenti, A.; Hall, R. A.; Schlicker, C.; Mühlschlegel, F. A.; Supuran, C. T. Bioorg. Med. Chem. 2009, 17, 2654; (d) Innocenti, A.; Leewattanapasuk, W.; Mühlschlegel, F. A.; Mastrolorenzo, A.; Supuran, C. T. Bioorg. Med. Chem. Lett. 2009, 19, 4802.

10. (a) Hall, R. A.; Mühlschlegel, F. A. Fungal and nematode carbonic anhydrases: Their inhibition in drug design In Supuran, C. T., Winum, J. Y., Eds.; Drug Design of Zinc-Enzyme Inhibitors: Functional, Structural, and Disease Applications; John Wiley \& Sons: Hoboken, 2009; pp 301-322; (b) Ohndorf, U. M.; Schlicker, C.; Steegborn, C. Crystallographic studies on carbonic anhydrases from fungal pathogens for structure-assisted drug development. In Drug Design of ZincEnzyme Inhibitors: Functional; Supuran, C. T., Winum, J. Y., Eds.; Structural, and Disease Applications; John Wiley \& Sons: Hoboken, 2009; pp 323-334.

11. (a) Klengel, T.; Liang, W. J.; Chaloupka, J.; Ruoff, C.; Schropel, K.; Naglik, J. R.; Eckert, S. E.; Mogensen, E. G.; Haynes, K.; Tuite, M. F.; Levin, L. R.; Buck, J.; Mühlschlegel, F. A. Curr. Biol. 2005, 15, 2021; (b) Bahn, Y. S.; Cox, G. M.; Perfect, J. R.; Heitman, J. Curr. Biol. 2005, 15, 2013.

12. (a) Mogensen, E. G.; Janbon, G.; Chaloupka, J.; Steegborn, C.; Fu, M. S.; Moyrand F.; Klengel, T.; Pearson, D. S.; Geeves, M. A.; Buck, J.; Levin, L. R.; Mühlschlegel, F. A. Eukaryot. Cell 2006, 5, 103; (b) Bahn, Y. S.; Mühlschlegel, F. A. Curr. Opin. Microbiol. 2006, 9, 572.

13. (a) Innocenti, A.; Scozzafava, A.; Supuran, C. T. Bioorg. Med. Chem. Lett. 2009, 19 1855; (b) Innocenti, A.; Scozzafava, A.; Supuran, C. T. Bioorg. Med. Chem. Lett. 2010, 20, 1548.

14. Temperini, C.; Scozzafava, A.; Supuran, C. T. Bioorg. Med. Chem. Lett. 2010, 20 474.

15. Isik, S.; Kockar, F.; Arslan, O.; Ozensoy Guler, O.; Innocenti, A.; Supuran, C. T. Bioorg. Med. Chem. Lett. 2008, 18, 6327.

16. Syriänen, L: Tolvanen, M.; Hilvo, M. Olatubosun, A- Innocenti, A. Scozzafava, A.; Leppiniemi, J.; Niederhauser, B.; Hytönen, V. P.; Gorr, T. A.; Parkkila, S.; Supuran, C. T. B. M. C. Biochemistry 2010, 11, 28.

17. Carta, F.; Aggarwal, M.; Maresca, A.; Scozzafava, A.; McKenna, R.; Supuran, C. T. Chem. Commun. in press, doi:10.1039/C2CC16395K.

18. Kolayli, S.; Karahalil, F.; Sahin, H.; Dincer, B.; Supuran, C. T. J. Enzyme Inhib. Med. Chem. 2011, 26, 895.

19. (a) Suarez Covarrubias, A.; Larsson, T. A. Hogbom, M. Lindberg J.; Bergfors, T; Bjorkelid, C.; Mowbry, S. L.; Unge, T.; Jones, T. A. J. Biol. Chem. 2005, 280, 18782; (b) Suarez Covarrubias, A.; Bergfors, T.; Jones, T. A.; Hogbom, M. J. Biol. Chem 2006, 281, 4993; (c) Minakuchi, T.; Nishimori, I.; Vullo, D.; Scozzafava, A.; Supuran, C. T. J. Med. Chem. 2009, 52, 2226; (d) Nishimori, I.; Minakuchi, T. Vullo, D.; Scozzafava, A.; Innocenti, A.; Supuran, C. T. J. Med. Chem. 2009, 52, 3116 .

20. Khalifah, R.G. J. Biol. Chem. 1971, 246, 2561. An Applied Photophysics stoppedflow instrument has been used for assaying the $\mathrm{CA}$ catalysed $\mathrm{CO}_{2}$ hydration activity. Phenol red (at a concentration of $0.2 \mathrm{mM}$ ) has been used as indicator working at the absorbance maximum of $557 \mathrm{~nm}$, with $10-20 \mathrm{mM}$ Hepes $(\mathrm{pH}$ 7.5 , for $\alpha$-CAs) or TRIS ( $\mathrm{pH} 8.3$ for $\beta$-CAs) as buffers, and $20 \mathrm{mM} \mathrm{Na}_{2} \mathrm{SO}_{4}$ (for $\alpha$ CAs) or $20 \mathrm{mM} \mathrm{NaCl}-$ for $\beta$-CAs (for maintaining constant the ionic strength), following the initial rates of the $\mathrm{CA}$-catalyzed $\mathrm{CO}_{2}$ hydration reaction for a period of $10-100 \mathrm{~s}$. The $\mathrm{CO}_{2}$ concentrations ranged from 1.7 to $17 \mathrm{mM}$ for the determination of the kinetic parameters and inhibition constants. For each inhibitor at least six traces of the initial $5-10 \%$ of the reaction have been used for determining the initial velocity. The uncatalyzed rates were determined in the same manner and subtracted from the total observed rates. Stock solutions of inhibitor $(10 \mathrm{mM})$ were prepared in distilled-deionized water and dilutions up to $0.01 \mathrm{nM}$ were done thereafter with distilled-deionized water. Inhibitor and enzyme solutions were preincubated together for $15 \mathrm{~min}$ at room temperature prior to assay, in order to allow for the formation of the E-I complex. The inhibition constants were obtained by non-linear least-squares methods using PRISM 3, whereas the kinetic parameters for the uninhibited enzymes from Lineweaver-Burk plots, as reported earlier, ${ }^{19 c, 19 d, 21}$ and represent the mean from at least three different determinations.

21. Pacchiano, F.; Carta, F.; Vullo, D.; Scozzafava, A.; Supuran, C. T. Bioorg. Med Chem. Lett. 2010, 20, 102.

22. International Programme of Chmical safety, available at: http://www wpro.who.int/NR/rdonlyres/ED05F324-B487-4B7F-A240-16DBA39AD994/0/ Environmentalhealthcriteria78dithiocarbamatepesticidesethelynethioureaand propylenethioureaageneralintroduction.pdf.

23. (a) Tsai, H. F.; Krol, A. A.; Sarti, K. E.; Bennett, J. E. Antimicrob. Agents Chemother 2006, 50, 1384; (b) Ramage, G.; Wickes, B. L.; Lopez-Ribot, J. L. Am. Clin. Lab 2001, 20, 42.

24. (a) Pai, M.; Turpin, R.; Garey, K. Antimicrob. Agents Chemother. 2007, 51, 35; (b) Kaur, R.; Domergue, R.; Zupancic, M. L.; Cormack, B. P. Curr. Opin. Microbiol. 2005, 8, 378; (c) Hitchcock, C. A.; Pye, G. W.; Troke, P. F.; Johnson, E. M. Warnock, D. W. Antimicrob. Agents Chemother. 1993, 37, 1962; (d) Fidel, P. L., Jr.; Vazquez, J. A.; Sobel, J. D. Clin. Microbiol. Rev. 1999, 12, 80. 